\title{
The Impact of Education on Intergenerational Mobility: Based on the 2015 CGSS Database
}

\author{
Yiqing Li \\ College of Economics, Jinan University, Guangzhou, China \\ Email: 18702600837@163.com
}

How to cite this paper: Li, Y. Q. (2020). The Impact of Education on Intergenerational Mobility: Based on the 2015 CGSS Database. Modern Economy, 11, 570-580. https://doi.org/10.4236/me.2020.112042

Received: January 16, 2020

Accepted: February, 24, 2020

Published: February, 27, 2020

Copyright (C) 2020 by author(s) and ScientificResearch Publishing Inc.

This work is licensed under the CreativeCommons Attribution International

License (CC BY 4.0)

http://creativecommons.org/licenses/by/4.0/

\begin{abstract}
Children's socioeconomic status is affected by both education and family background. On the one hand, education helps to enhance the mobility and ability of lower-level groups. On the other hand, the opportunity for education is greatly affected by family background. Based on the 2015 CGSS database, this paper makes a statistical analysis of the current intergenerational mobility of Chinese residents and replaces the impact of family background on the social status of the offspring with the educational level of the parents. This paper applies regression models to analyze the impact of education on intergenerational mobility. The results show that children of families with less educated parents are often difficult to get rid of the disadvantages of family background and jump to a higher status. For families with higher education, it is easy for children to maintain the superior work status of their parents.
\end{abstract}

\section{Keywords}

Socioeconomic Status Index, Education, Intergenerational Mobility

\section{Introduction}

At present, China is in a period of two-hundred-year historical confluences. Education plays an important role in improving the quality of talents and promoting social development. Efforts to make every child enjoy a fair and quality education are the goal put forward in the report of the 19th CPC National Congress. The poor can rely on knowledge and education to realize the upward development of life, and then change their destiny and achieve stride crossing. The smoothness of intergenerational mobility is related to national stability and economic development. In China, people have attached great importance to education. The gross enrollment rate of higher education has increased sharply from $9.8 \%$ in 1998 to $34.5 \%$ in 2013 since the expansion of education in 1999 . 
People born in the 1960s and 1970s can basically get rid of the influence of their family background by receiving tertiary education, and by their own efforts to find a good job, so as to achieve intergenerational mobility. But now the topics of graduates, for example, a college diploma is worthless, my dad is Li Gang and so on make us wonder: Can education really change destiny? Is intergenerational mobility difficult? Zou \& Ma (2019) confirmed that access to educational opportunities is affected by the socioeconomic status of families. Zhao (2017) pointed out that the intergenerational mobility of education in China is not high. According to the transmission of education, the education level of the father will be passed to the children to some extent. Access to education has a significant impact. Cheng \& Ren (2018) pointed out that different levels of social capital play different roles in intergenerational mobility of rural families, and family kinship is more likely to provide children with competitive social resources. Based on the latest data from the China General Social Survey (CGSS) in 2015, the issue of intergenerational mobility in China is discussed from the perspective of education.

\section{Literature Review}

Intergenerational mobility generally refers to the changes in the socio-economic status of the offspring compared to the parent. This study uses the change in the influence of the socio-economic status of the parent on the socio-economic status of the offspring as a substitute. Socioeconomic status refers to the economic, social, cultural and human capital resources available to a person. Coleman (1988) pointed out that the impact of family human capital, economic capital and social capital on the educational attainment of offspring is greater than the impact of school quality on it, and children with superior strata background often have an advantageous position in educational attainment. Brown \& Park (2002) pointed out that the intergenerational transmission of education in the family starts with the parents' ability and education level. If the parents' education level is high, they will have a relatively high income, so the better the family background, the more Being able to create a superior educational environment for the offspring, the education of the offspring is correspondingly higher. Zhou \& Zhang (2014) found that education can significantly reduce the probability of intergenerational downward mobility and increase the opportunity for upward mobility.

Sun (2015) tested the distribution of educational opportunities at various educational stages using the Logit model. The results show that the educational background of fathers and mothers affects children's educational opportunities at different stages. The influence of father's educational background on children's educational opportunities is significant in the higher education stage, while the influence of mother's educational background on children's educational opportunities is more significant in compulsory education and high school. Zhang (2016) showed that the elasticity of intergenerational education mobility is gen- 
erally upward, and that the acquisition of parental education has a long-lasting and more significant effect on the education of offspring. Intergenerational education has reduced mobility. Xu \& Huang (2016) used a new intergenerational mobility index to measure the regional, urban, rural, and class differences in the intergenerational mobility of education in China, and the index has good mathematical characteristics. Li (2012a) believes that fathers' political capital, human capital, marriage status, and income also play important roles. Zhong (2013) deduced the impact of education reform on intergenerational mobility from a theoretical level. He assumed that family background has a positive impact on education returns. In the case of higher education enrollment, education will lead to differences in educational opportunities and inefficient accumulation of human capital. Zhou, Li, \& Cui (2018) believe that education, as an important tool for intergenerational reproduction, is an important intermediary mechanism for the social elite to realize the intergenerational transfer of resources. Individual specific prerequisite conditions will affect the access to educational opportunities.

\section{Theoretical Framework}

To explore the impact of education expansion on intergenerational mobility, we need to understand the relationship between education, family background, and socioeconomic status. Here, education can be seen as playing an intermediary role and adjustment in the relationship between family background and socioeconomic status in the first job effect. Intermediary role means that the family background indirectly affects the social and economic status of the interviewee by affecting the education level of the respondent. The moderating effect refers to the influence of the family background on the interviewee's initial employment socioeconomic status, or the strength of the interviewee's education level. The equalization effect of the expansion of education enrollment is based on the mediating role of education, while the structural effect of the expansion of education enrollment essentially tests the moderating role of education. This moderating effect can be achieved through the interaction between variables.

The socioeconomic status of the child's first employment is obtained through the pre-approval effect, that is, the parents pass the socioeconomic status to the child through economic capital, social capital, and cultural capital. Mobility and education can be seen as an important result of effort, and of course includes certain qualities and skills that are difficult to measure. At the same time, parents' socio-economic capital will also have an impact on their children's educational attainment. Different social strata have very different materials and human capital resources. This difference will become an unequal educational opportunity under the catalyst of biased policies and an educational process caused by the uneven distribution of educational resources. Inequality worsens educational inequality, which in turn results in significant differences in educational attainment and educational returns between different strata. In the end, more 
people who have received education have a greater advantage in entering the upper classes of society.

When the dependent variable is the socioeconomic status index of the interviewee's first employment, the measurement model is as follows:

$$
Y=\alpha+\beta_{1} X_{1}+\beta_{2} X_{2}+\beta_{3} X_{2} * X_{1}+\beta_{4} X_{3}+\mu
$$

among them, $\beta_{j}$ is the regression coefficient, $\mu$ is the error term. $X_{1}$ and $X_{2}$ represent the educational level and family background of the interviewee, $X_{3}$ representative gender, Control variables such as household registration, age, and square terms of age. $X_{2}{ }^{*} X_{1}$ Interaction term represents family background and education level. If the regression coefficient $\beta_{3}$ is significant. It shows that the level of education can regulate the influence of family background on the socioeconomic status of individuals' first employment.

\section{Data and Variables}

The data in this article are from the 2015 China General Social Survey (CGSS) survey database.

The dependent variable is the socioeconomic status of the interviewee. To measure the socioeconomic status, the CGSS database uses the occupation classification and code table used in the fifth national census. This article intends to use the International Socio-Economic Index (ISEI). This is an indicator for measuring social status based on occupation. Originally, Blau et al. (1967) multiplied the average income of each occupation and the required education level by the corresponding socioeconomic characteristics of various occupations. The weights are calculated. Later, Ganzeboom et al. (1992) made improvements. This indicator assumes that the level of income and education determines the level of social status, but actually measures people's comprehensive social status, and has been widely used in areas such as status acquisition and social mobility (Li, 2005). Li (2012b) believes that the Socio-Economic Status Index of the First International Employment is based on a combination of a variety of socio-economic factors in the theory. Convert the occupation code used by CGSS into the Socioeconomic Status Index of International First Employment.

The independent variables mainly include the education level and family background of the respondent. Among them, the surrogate variables of family background are the socioeconomic status index of the first employment of fathers and mothers and the educational level of parents.

The key variable of the interviewee's education level, from the information available in the questionnaire, is to convert the answer to the question of your current highest level of education into the number of years of education: 0 years without any education and 3 years of private education 6 years for literacy classes and elementary schools, 9 years for junior high schools, 12 years for vocational high schools, ordinary high schools, technical secondary schools and technical schools, 15 years for college colleges, 16 years for undergraduates, and 19 years for graduate students, ignore it. From the correlation between the edu- 
cation level of the offspring and the parent, the educational level of the parents is significantly higher than that of the offspring at a significant level of $5 \%$, as shown in Table 1.

Control variables include demographic variables such as the respondent's gender, household registration, age, and square terms of age, as well as factors such as the type of employment sector. From the perspective of labor market segmentation: looking at the socioeconomic status of education returns requires consideration of sectoral differences (Liu, 2006). CGSS surveyed the nature of ownership of the respondent's work unit. This article classifies state-owned or state-controlled, collectively owned or collectively-owned as a state-owned sector, privately or privately-owned or privately-owned or privately-held, Hong Kong, Macao, or Taiwan-owned Foreign ownership or foreign ownership is classified as a non-state sector. Assign dummy variables to 0 for non-state sector and 1 for state sector. For household registration, the questionnaire survey is divided into 8 types: agricultural account, non-agricultural account, blueprint account, resident account (formerly agricultural account or non-agricultural account), military registration, no account and other 8 types. For the convenience of analysis, this article is only divided into two types: agricultural account and non-agricultural account. Excluding the blue print account, no account, other and military status, the agricultural account is used as the reference group. Women are the reference group.

According to questionnaire survey A43, "In our society, some people are at the top of the society and some are at the bottom of the society". What do you think you are now at the level you were 10 years ago, 10 years later, as a result of the "level of the family at the age of 14 " statistics, we eliminated the answer "no answers" people labeled 1 and 2 consider "lower society". Labels 3 to 4 are considered "lower middle", 5 and 6 are considered "middle", and 7 to 8 are "upper". 9 and 10 are "Upper society". As shown in Table 2, from the current level, $34.65 \%$ of the respondents indicated that they were in the fifth level, and nearly $46.2 \%$ were in the middle level; while those above the 9 level did not exceed $0.73 \%$. Compared with the level 10 years ago, nearly $23.94 \%$ of people think that they are at the 1.2 level, and they are in the lower stratum of the society. They are a large proportion of people, and only $26.15 \%$ think that they were in the middle 10 years ago. Level indicates that people's living conditions are

Table 1. Intergenerational relevance of education.

\begin{tabular}{cccc}
\hline Intergenerational relevance of education & $\begin{array}{c}\text { Education } \\
\text { level }\end{array}$ & $\begin{array}{c}\text { Education level } \\
\text { of father }\end{array}$ & $\begin{array}{c}\text { Education level } \\
\text { of mother }\end{array}$ \\
\hline Education level & 1 & 1 \\
Education level of father & $0.2674^{*}$ & 0.0000 & $0.5618^{*}$ \\
Education level of mother & $0.2366^{*}$ & 0.0000 & 1 \\
\hline
\end{tabular}


Table 2. Respondents' perception of social status.

\begin{tabular}{ccccc}
\hline Level & $\begin{array}{c}\text { At what level } \\
\text { do you think } \\
\text { you are currently? }\end{array}$ & $\begin{array}{c}\text { At what level } \\
\text { do you think } \\
\text { you were } \\
10 \text { years ago? }\end{array}$ & $\begin{array}{c}\text { At what level } \\
\text { do you think } \\
\text { you will be } \\
\text { in 10 years? }\end{array}$ & $\begin{array}{c}\text { What do you } \\
\text { think was the } \\
\text { family level } \\
\text { when you were } \\
14 \text { years old? }\end{array}$ \\
\hline Cannot answer & 0.97 & 1.35 & 5.82 & 1.74 \\
1 (Lowest level) & 7.70 & 13.46 & 4.86 & 20.79 \\
2 & 6.48 & 13.48 & 4.57 & 21.08 \\
3 & 13.42 & 21.13 & 8.42 & 19.94 \\
5 & 18.66 & 19.81 & 11.62 & 13.85 \\
6 & 34.65 & 19.90 & 22.08 & 14.49 \\
7 & 11.55 & 6.25 & 19.21 & 4.25 \\
8 & 4.39 & 2.76 & 12.76 & 1.91 \\
9 & 1.44 & 1.08 & 7.30 & 1.08 \\
10 (Top most) & 0.25 & 0.34 & 1.84 & 0.55 \\
Total & 0.48 & 0.43 & 1.53 & 0.34 \\
\hline & 100.00 & 100.00 & 100.00 & 100.00 \\
\hline
\end{tabular}

unsatisfactory around 2005; and in predicting their future social status, only 9.43\% believe that they are still at the bottom of the society; more than $41.29 \%$ expect that they are in the middle Level, and the number of people who are expected to rise to the upper-middle level is $14.23 \%$ more than the original, and the number of people who have risen to the top of the society is as high as $3.37 \%$, indicating that the people are still confident in the change of their social status in the next 10 years. Compared with the parents' generation (that is, the social grade of the family at the age of 14 ), more than $41.87 \%$ of the respondents thought that their family was at the bottom of the society, which is more than three times that of the current level. Less than $20 \%$ of people think that their family level is in the middle of society, and obviously many descendants have realized class mobility.

This is just the level of personal cognition, which needs to match the level of social development and the people's level of understanding at that time. But from the perspective of personal cognition, we can also roughly determine the existence of intergenerational mobility.

\section{Empirical Results}

Using a simple linear regression model, the conclusions are detailed in Table 3. From this, we can draw the effect of education and family background on intergenerational mobility. Models (1) and (2) respectively show the influence of the control variable that adds the individual characteristics of the offspring on the socioeconomic status index of the first employment of the offspring under a small sample. 
Table 3. Regression results and robustness tests.

\begin{tabular}{|c|c|c|c|c|c|}
\hline Socioeconomic status index & $\begin{array}{c}\text { (1) } \\
\text { Full sample }\end{array}$ & $\begin{array}{l}\text { (2) } \\
\text { Full sample }\end{array}$ & $\begin{array}{c}\text { (3) } \\
\text { Lower society }\end{array}$ & $\begin{array}{c}\text { (4) } \\
\text { Middle class }\end{array}$ & $\begin{array}{c}(5) \\
\text { Upper class }\end{array}$ \\
\hline $\begin{array}{l}\text { Socioeconomic status } \\
\text { index of father }\end{array}$ & $\begin{array}{l}-0.446^{* * *} \\
(-4.08)\end{array}$ & $\begin{array}{l}-0.534^{* * *} \\
(-4.67)\end{array}$ & $\begin{array}{l}0.000 \\
(0.22)\end{array}$ & $\begin{array}{l}0.001 \\
(0.82)\end{array}$ & $\begin{array}{l}-0.001 \\
(-0.80)\end{array}$ \\
\hline $\begin{array}{l}\text { Socioeconomic status } \\
\text { index of mother }\end{array}$ & $\begin{array}{l}0.130^{* * *} \\
(3.42)\end{array}$ & $\begin{array}{l}0.066^{*} \\
(1.87)\end{array}$ & $\begin{array}{l}-0.001^{* *} \\
(-2.25)\end{array}$ & $\begin{array}{l}-0.000 \\
(-0.11)\end{array}$ & $\begin{array}{l}0.001^{* *} \\
(2.00)\end{array}$ \\
\hline \multicolumn{6}{|l|}{ Years of education } \\
\hline Elementary and below & $\begin{array}{l}-28.757^{* *} \\
(-2.51)\end{array}$ & $\begin{array}{c}-17.511^{* * *} \\
(-2.90)\end{array}$ & $\begin{array}{l}-0.048 \\
(-0.49)\end{array}$ & $\begin{array}{l}-0.028 \\
(-0.46)\end{array}$ & $\begin{array}{l}0.132 \\
(1.17)\end{array}$ \\
\hline College & $\begin{array}{c}-20.605^{\star} \\
(-1.88)\end{array}$ & $\begin{array}{l}-8.170 \\
(-1.44)\end{array}$ & $\begin{array}{l}0.125 \\
(1.32)\end{array}$ & $\begin{array}{l}0.024 \\
(0.41)\end{array}$ & $\begin{array}{l}-0.107 \\
(-0.97)\end{array}$ \\
\hline Undergraduate & $\begin{array}{c}-20.515^{*} \\
(-1.87)\end{array}$ & $\begin{array}{l}-9.270^{*} \\
(-1.65)\end{array}$ & $\begin{array}{l}0.056 \\
(0.60)\end{array}$ & $\begin{array}{l}0.023 \\
(0.38)\end{array}$ & $\begin{array}{l}-0.037 \\
(-0.34)\end{array}$ \\
\hline Postgraduate & $\begin{array}{l}23.225^{* * *} \\
(2.62)\end{array}$ & $\begin{array}{l}29.319^{* * *} \\
(5.27)\end{array}$ & $\begin{array}{l}-0.051 \\
(-0.57)\end{array}$ & $\begin{array}{l}-0.056 \\
(-0.81)\end{array}$ & $\begin{array}{l}0.174 \\
(1.58)\end{array}$ \\
\hline Years of father's education & $\begin{array}{l}0.072 \\
(1.35)\end{array}$ & $\begin{array}{c}0.127^{* * *} \\
(2.75)\end{array}$ & $\begin{array}{l}0.000 \\
(0.62)\end{array}$ & $\begin{array}{l}0.000 \\
(0.62)\end{array}$ & $\begin{array}{l}-0.002^{\star *} \\
(-1.97)\end{array}$ \\
\hline Years of mother's education & $\begin{array}{l}-0.034 \\
(-0.60)\end{array}$ & $\begin{array}{l}0.063 \\
(1.24)\end{array}$ & $\begin{array}{l}-0.002^{* * *} \\
(-2.75)\end{array}$ & $\begin{array}{l}0.000 \\
(0.54)\end{array}$ & $\begin{array}{l}0.002^{* *} \\
(2.40)\end{array}$ \\
\hline $\begin{array}{l}\text { Socioeconomic status of } \\
\text { father }{ }^{*} \text { Primary and below }\end{array}$ & $\begin{array}{l}0.538^{* *} \\
(2.46)\end{array}$ & $\begin{array}{l}0.559^{* * *} \\
(3.34)\end{array}$ & $\begin{array}{l}0.002 \\
(1.21)\end{array}$ & $\begin{array}{l}-0.001 \\
(-0.79)\end{array}$ & $\begin{array}{l}-0.001 \\
(-0.50)\end{array}$ \\
\hline Socioeconomic status of father ${ }^{*}$ & $\begin{array}{c}0.000 \\
(.)\end{array}$ & $\begin{array}{c}0.000 \\
(.)\end{array}$ & & & \\
\hline $\begin{array}{l}\text { Socioeconomic status } \\
\text { of father }{ }^{*} \text { Bachelor }\end{array}$ & $\begin{array}{c}0.523^{* * *} \\
(4.68)\end{array}$ & $\begin{array}{c}0.569^{* * \star} \\
(4.91)\end{array}$ & $\begin{array}{l}-0.000 \\
(-0.58)\end{array}$ & $\begin{array}{l}0.000 \\
(0.31)\end{array}$ & $\begin{array}{l}0.000 \\
(0.05)\end{array}$ \\
\hline $\begin{array}{l}\text { Socioeconomic } \\
\text { status of father }\end{array}$ & $\begin{array}{c}0.559^{* * *} \\
(5.04)\end{array}$ & $\begin{array}{c}0.623^{\star * *} \\
(5.42)\end{array}$ & $\begin{array}{l}0.000 \\
(0.60)\end{array}$ & $\begin{array}{l}-0.000 \\
(-0.28)\end{array}$ & $\begin{array}{l}0.000 \\
(0.08)\end{array}$ \\
\hline gender & & $\begin{array}{l}1.089 \\
(1.56)\end{array}$ & $\begin{array}{c}-0.035^{\star * *} \\
(-3.97)\end{array}$ & $\begin{array}{c}-0.011^{* *} \\
(-2.18)\end{array}$ & $\begin{array}{c}0.042^{\star * *} \\
(4.39)\end{array}$ \\
\hline Household registration & & $\begin{array}{c}4.750^{\star * \star} \\
(5.52)\end{array}$ & $\begin{array}{c}0.076^{\star * *} \\
(6.35)\end{array}$ & $\begin{array}{c}0.054^{\star \star \star} \\
(6.98)\end{array}$ & $\begin{array}{l}-0.146^{\star * *} \\
(-11.21)\end{array}$ \\
\hline Party ember & & $\begin{array}{c}13.018^{\star * *} \\
(10.66)\end{array}$ & $\begin{array}{c}-0.072^{\star * *} \\
(-4.98)\end{array}$ & $\begin{array}{c}0.086^{\star * *} \\
(6.20)\end{array}$ & $\begin{array}{c}-0.040^{* *} \\
(-2.20)\end{array}$ \\
\hline age & & $\begin{array}{c}-0.840^{\star * *} \\
(-7.10)\end{array}$ & $\begin{array}{l}0.001 \\
(0.99)\end{array}$ & $\begin{array}{c}-0.003^{* * *} \\
(-3.09)\end{array}$ & $\begin{array}{l}0.002 \\
(1.09)\end{array}$ \\
\hline Square term of age & & $\begin{array}{c}0.010^{* * *} \\
(8.17)\end{array}$ & $\begin{array}{l}0.000 \\
(0.36)\end{array}$ & $\begin{array}{c}0.000^{* * *} \\
(5.25)\end{array}$ & $\begin{array}{c}-0.000^{* * *} \\
(-4.10)\end{array}$ \\
\hline _cons & $55.120^{* * *}$ & $54.970^{* * *}$ & 0.051 & 0.011 & $0.910^{* * *}$ \\
\hline & $(5.04)$ & $(9.11)$ & $(0.51)$ & $(0.17)$ & $(7.80)$ \\
\hline $\mathrm{N}$ & 1931 & 1931 & 7821 & 7821 & 7821 \\
\hline
\end{tabular}

$\mathrm{t}$ statistics in parentheses ${ }^{*} p<0.1,{ }^{* *} p<0.05,{ }^{* * *} p<0.01$. 
The analysis models (1) and (2) can conclude:

1) In both models, the father's socioeconomic status index has a negative impact on the offspring's first socioeconomic status index, and is significant at a significance level of $1 \%$. It shows that when the offspring is employed for the first time, the overall job selection does not seem to exceed the father's occupation. Although the questionnaire shows the interviewee's father's occupation status when he was 14 years old. Generally speaking, in the course of 14 years, his father's work has stabilized and his socioeconomic status has become fixed. For young children entering the workplace, it is obviously difficult to reach.

2) The socioeconomic status index of the mother and the socioeconomic status index of the offspring are positive regression coefficients in both models. Model (1) is significant at the $1 \%$ level of significance and does not consider other control variables; the significance level of the regression coefficient decreases significantly with the increase of control variables. But it also shows that the socioeconomic status of the mother has an impact on the first employment of the offspring.

3) Observe the interaction between the father's socioeconomic status index and education level. Except for the regression coefficient of the interaction between the father's socioeconomic status index and college education, the other academic levels and the father's socioeconomic status index are positive, at least Significant at the $5 \%$ significance level. It shows that education can weaken the effect of family background on the first employment of offspring.

4) After controlling for other variables, the father's education level and the socioeconomic status index of the offspring's first employment were significantly positively correlated at the $1 \%$ level. This shows that the higher the father's education level, the more emphasis is placed on their children's career choices, and the more likely they are to help them choose jobs with high socioeconomic status.

5) The impact of the education level of the respondents on the socioeconomic status index of the first employment, as the education level increased, the impact also changed from a negative significant correlation to a positive significant correlation, which is in line with experience. When the respondents' education level is low, they have fewer choices of employment opportunities, low technical content in their jobs, and lower socioeconomic status; as the level of education rises, the more qualified they are for more demanding positions, the higher their social status.

6) In the data in this article, gender is not important when choosing a career for the first time. Instead, household registration and party membership are important. It can be explained that in China, there are more restrictions on foreigners working locally without hukou, and employers are also worried about staff turnover. For those who are employed for the first time, party status generally represents a signal of excellence. And age is negatively correlated at a significant level of $1 \%$. Younger children who work will generally receive less education and the socioeconomic status of work will be relatively low. For example, 
the children who work after graduating from junior high school are generally difficult to choose high-paying jobs; while the older children who are working for the first time may be doctors, masters, college students, etc., with a high level of education, are more likely to get high-paying, high-status occupations.

\section{Robustness Test}

Simple regression for small samples is likely to cause large deviations. Models (3) to (5) in Table 3 indicate the stratification of the socioeconomic status index of the offspring's first employment, and the impact of education and family background on the intergenerational mobility at the three levels serves as a stability test. Stratified according to the socioeconomic status index and occupation type, and then regression of the socioeconomic status index of the offspring according to the measurement formula, it can be found that:

1) Among the three classes, the socioeconomic status index of the father was not significant for the socioeconomic status index of the offspring's first employment.

2) The socioeconomic status index of the mother and the mother's years of education are in the model (3). The coefficient of the socioeconomic status index of the offspring of the lower society is significant at a significance level of 5\%, and it is a negative relationship. The higher the mother's socioeconomic status, the less likely her offspring will find employment for the first time. As the social hierarchy of the offspring rises, the estimated coefficient of the influence of the mother's socioeconomic status index on the socioeconomic status index of the offspring's first employment is positive, which is significant at the significant level of $10 \%$ in model (5), indicating the higher the mother's socio-economic status, the more likely it is that the child will be employed for the first time in employment. From the side, it shows the importance of mothers to their children's education.

3) The regression coefficients on the interaction terms of family background and education level were observed to be not significant in the three models. It shows that education does not play a regulating role in different family backgrounds.

4) For the analysis of other control variables, gender differs in the specific socioeconomic status levels. At the lower and middle levels of society, the regression coefficient of gender is negative and significant at a significance level of $1 \%$, indicating that there is gender discrimination. At the upper levels of society, the regression coefficient of gender is positive, indicating that there is less sex discrimination. Household registration is also valued at the lower and middle levels of society, but not at the upper levels. One explanation is that in the lower and middle classes of society, employment pressure is much greater than in the upper classes, so any resource that can increase personal endowment is very important; those who can be in the upper classes often have a certain endowment that is far beyond On average, no other resources are needed to increase its scarcity. The identity of the party member can also be used to explain the regression 
coefficients of the middle and upper levels of society. However, the explanation for the regression coefficients of the lower layers of the society is significantly negative. The explanation is that as a signal of "excellent talent", the status of party members has not reached the release. The signal of "excellent talent" and a lower occupational status will make employers doubt this person's ability.

\section{Suggestions and Discussions}

Based on the data of CGSS2015, the analysis of the impact of education on intergenerational mobility is shown. There are obvious intergenerational transmission phenomena in the economic capital, social capital and cultural capital of Chinese residents, and the scope of intergenerational mobility has a more obvious segmentation feature. Work, as an important identification mark of the social class to which an individual belongs, also has obvious characteristics of labor market segmentation. Children of families with lower working status often find it difficult to get rid of the influence of family background disadvantages and jump to higher working status. For high-income families, it is easy for children to maintain their parents' advantageous working position and the possibility of downward mobility is also lower.

Children's socioeconomic status is affected by both education and family background. Education helps to improve intergenerational mobility and enhance the opportunities and ability of lower-level groups to escape from family poverty and upward mobility. However, it cannot be ignored that education can only guarantee the realization of intergenerational mobility under the conditions of fair education. Otherwise, educational inequality will evolve into an important mechanism of social inequity and social stratified reproduction. The upper strata of the society make use of various resource advantages to promote their children's access to better educational opportunities, educational processes and educational results in order to maintain their status Intergenerational transmission, resulting in the solidification of the class. And the more severe the social differentiation, the more limited the role of education, and the weaker the intergenerational mobility.

\section{Conflicts of Interest}

The authors declare no conflicts of interest regarding the publication of this paper.

\section{References}

Blau, P. M., Duncan, O. D. \& Tyree, A. (1967). The American Occupational Structure. American Journal of Sociology, 33, 286-296. https://doi.org/10.2307/2092399

Brown, P. H., \& Park, A. (2002). Education and Poverty in Rural China. Economics of Education Review, 21, 523-541. https://doi.org/10.1016/S0272-7757(01)00040-1

Cheng, J., \& Ren, X. M. (2018). Current Challenges and Future Turns in Preferential Policies for Education in the New Situation: Based on the Perspective of Educational 
Equality. Journal of Hubei Institute for Nationalities (Philosophy and Social Sciences), No. 2, 166-171.

Coleman, J. S. (1988). Social Capital in the Creation of Human Capital. American Journal of Sociology, 94, 95-120. https://doi.org/10.1086/228943

Ganzeboom, H. B. G. et al. (1992). A Standard International Socio-Economic Index of Occupational Status. Social Science Research, 21, 1-56. https://doi.org/10.1016/0049-089X(92)90017-B

Li, C. L. (2005). Layer of Prestige in Contemporary Chinese Society-Measurement of Professional Reputation and Socioeconomic Status Index. Sociological Research, No. 2, 74-102.

Li, H. B. (2012a). Parents' Political Capital Affects the Performance of College Students in the Labor Market? An Empirical Study Based on the Employment Survey of Fresh Graduates in Chinese Universities. Economics (Quarterly), 11, 1011-1026.

Li, Q. (2012b). Social Stratification and Fairness and Justice in the Field of Social Space. Journal of Renmin University of China, No. 1, 4-16.

Liu, J. M. (2006). Labor Market Structure Changes and Human Capital Benefits. Sociology Research, No. 6, 89-119.

Sun, Y. Q. (2015). A Study on the Urban-Rural Differences in the Intergenerational Transmission of Education in China-An Empirical Analysis Based on the Chinese Family Tracking Survey. Journal of Beijing Normal University (Social Science Edition), No. 6, 59-67.

Xu, J. W., \& Huang, S. (2016). Study on the Regional, Urban-Rural and Strata Differences in the Intergenerational Education Mobility in China. Statistics and Decision, No. 8, 87-91.

Zhang, Y. H. (2016). Empirical Research on Educational Acquisition and Educational Mobility Shanghai University.

Zhao, H. X. (2017). The Impact of Child Education on the Intergenerational Transmission of Rural Poverty in China-An Empirical Analysis Based on CHIP. Education Monthly, 12, 26-32.

Zhong, H. (2013). Does Education Expansion Increase Intergenerational Mobility? Economica, 80, 760-773. https://doi.org/10.1111/ecca.12032

Zhou, S. J., Li, Q. Y, \& Cui, L. (2018). Parents' Education and Children's Education: An Empirical Investigation Based on CGSS Micro Data. Education and Economy, No. 3, 46-53.

Zhou, X., \& Zhang, P. (2014). Intergenerational Occupational Mobility and Income Mobility: An Empirical Study from Chinese Urban and Rural Households. Economics (Quarterly), No. 1, 351-372.

Zou, W., \& Ma, Z. L. (2019). Family Background, Intergenerational Transmission and Education Inequality. China Industrial Economy, No. 2, 80-98. 